\title{
"The effect of investor sentiment on the means of earnings management"
}

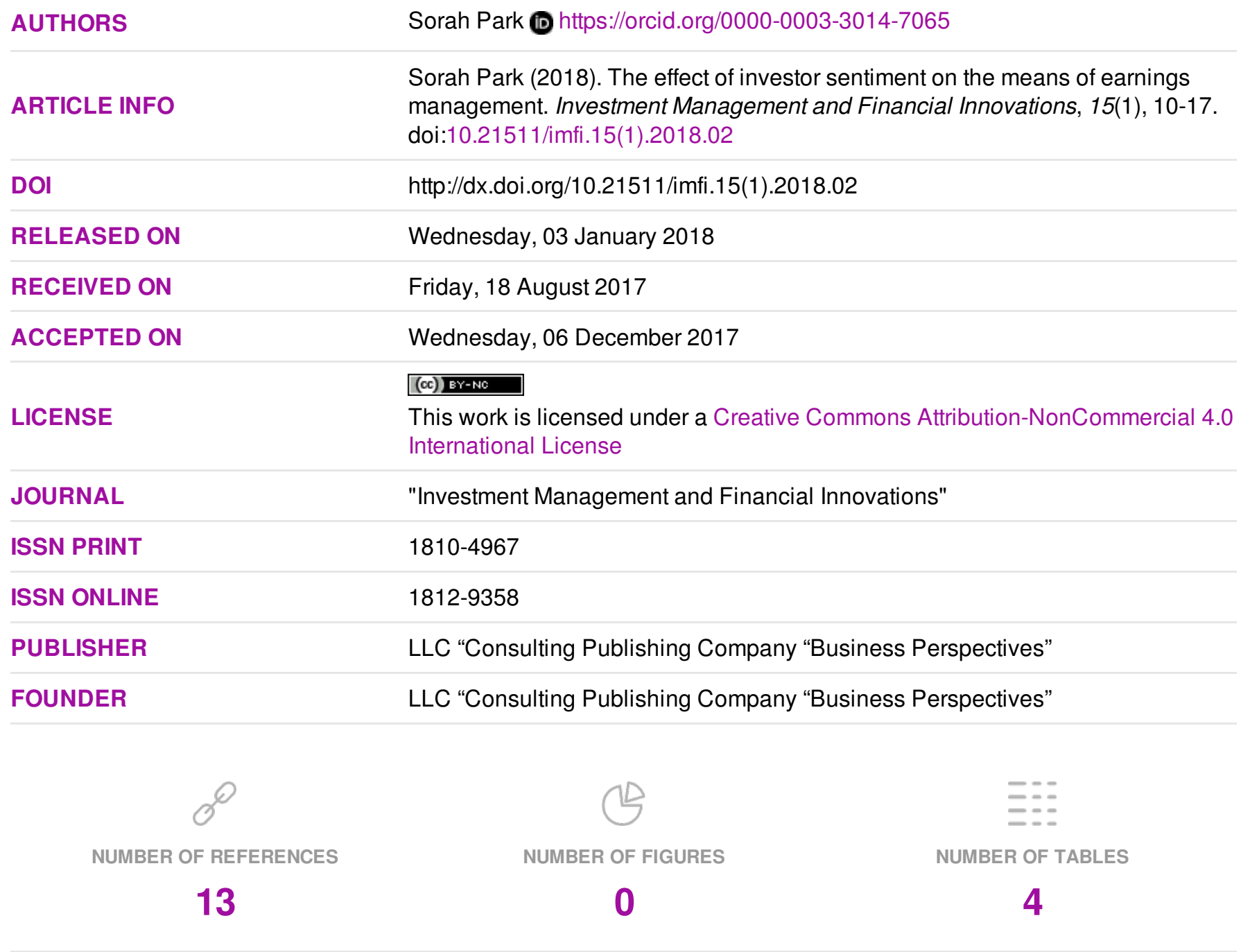

C The author(s) 2023. This publication is an open access article. 


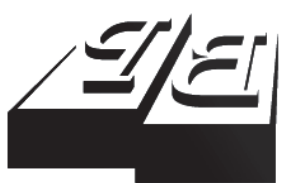

BUSINESS PERSPECTIVES

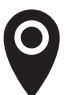

LLC "CPC "Business Perspectives" Hryhorii Skovoroda lane, 10, Sumy, 40022, Ukraine

www.businessperspectives.org

Received on: $18^{\text {th }}$ of August, 2017 Accepted on: $6^{\text {th }}$ of December, 2017

(C) Sorah Park, 2018

Sorah Park, Ph.D. in Accounting, Assistant Professor, Ewha School of Business, Ewha Womans University, Seoul, Korea.

\title{
THE EFFECT OF INVESTOR SENTIMENT ON THE MEANS OF EARNINGS MANAGEMENT
}

\begin{abstract}
Prior research has shown that a firm's tendency to meet or beat earning targets is greater during bad economic times than good times. The paper extends this line of research by investigating which means of earnings management is used in different states of economy. A sample of non-financial companies listed on Korea Securities Market from 2003 to 2011 is used for empirical tests. The findings of this study are summarized as follows. The magnitude of discretionary accruals is negatively related to investment sentiment, indicating that firms tend to use positive discretionary accruals to manipulate reported income upward when the sentiment is pessimistic. However, the real activity based earnings management is not significantly associated with the state of economy. Collectively, this study contributes to behavioral finance and accounting literature by suggesting that managers use discretionary portion of accruals, but do not change their real operating activities, in order to meet or beat earnings targets in economic downturn.
\end{abstract}

\section{Keywords}

JEL Classification earnings management, discretionary accruals, real earnings management, investor sentiment

\section{INTRODUCTION}

There is voluminous accounting research on earnings management, which is defined as "the purposeful intervention in the external financial reporting process with the intent of obtaining some private gain (Schipper, 1989). Prior research (e.g., Graham et al., 2005) has shown that firms tend to inflate earnings to a greater extent during the bad state of economy in order to distinguish themselves from others in the market by boosting stock prices in bad times. In Korea, Park (2015) also documents that firms' tendency to meet or beat earning targets is greater during pessimistic sentiment period.

The literature has detected two major means of earnings management: accrual-based and real-based earnings management. First, many prior studies find that accruals are used at managerial discretion to report more favorable income. For instance, Song et al. (2004) document the empirical results of firms with net income that is slightly below zero or with big loss manipulating earnings upward using accruals, suggesting that accrual-based earnings management is common in Korea. Second, firms may manipulate upward or smooth earnings by involving in abnormal management practices, which are reflected as abnormal operating cash flows, discretionary expenditures and production costs (Roychowdhury, 2006; Kim et al., 2008).

The choice of earnings management appears to vary with firm-specific characteristics and circumstances. For example, Zang (2012) shows 
that managers adjust the level of accrual manipulation according to the level of real activities manipulation realized, suggesting that managers trade off two methods of earnings management based on their relative costs. Also, Cohen and Zarowin (2010) find that firms' choice between real- and accrual-based earnings management around seasoned equity offerings is a function of firms' ability to use accrual management and the costs of doing so. However, little is known about how equity market sentiment affects the trade-off between real- and accrual-based earnings management. Hence, this paper examines the effect of investor sentiment on accrual-based and real-based earnings management.

The empirical tests of this paper are based on investor sentiment (Baker \& Wurgler, 2007) and the level of stock market (Conrad et al., 2002). Using a sample of public companies listed on Korea Securities Market from 2003 to 2011, the paper documents the following empirical test results. First, the magnitude of discretionary accruals is negatively associated with investment sentiment. This implies that firms tend to use positive discretionary accruals to manipulate earnings upward when the sentiment is pessimistic. Second, on the other hand, the real-based earnings management (i.e., operating activities, discretionary $\mathrm{R} \& \mathrm{D}$ expenditures and production activities)is not significantly related to investor sentiment. In sum, these findings suggest that firms do not depend on real activity manipulation, but rather inflate discretionary accruals to report favorable income in bad economic times. Such conclusion is consistent with Graham et al. (2005) arguing that managers are likely to boost earnings in recessions based on their expectation of reversal of intrinsic earnings in economy recovery.

These findings contribute to accounting and behavioral finance research on the relation between macroeconomic condition and financial reporting behavior. Behavioral research presumes that capital market participants including investors and managers are not completely rational in pricing stocks and processing information because they cannot be free from emotions. This study adds new evidence that managers do not manipulate operating activities to boost reported income in bad times, but they tend to rely on discretionary accruals, indicating that accrual quality is affected by sentiment.

The rest of the paper is organized as follows. Section 1 describes the research methods and sample selection. Section 2 reports the empirical test results and last section concludes this study.

\section{RESEARCH METHODOLOGIES}

\subsection{Variable measurement}

\subsubsection{Investor sentiment}

Investor sentiment is defined as the degree of optimism or pessimism about stocks that is not justified by fundamental information (Baker \& Wurgler, 2006, 2007). The empirical tests are based on three alternative measures of investor sentiment: KSENT, KBSENT, and DIFFPE.

KSENT and KBSENT are investor sentiment indices that are formed by Kim and Byun (2010), as in Baker and Wurgler $(2006,2007)$. Baker and Wurgler $(2006,2007)$ combine several imperfect sentiment proxies such as trading volume, divi- dend premium, closed-end fund discount, the number of initial price offerings, the first-day returns on IPOs, and the equity share in new issues to construct the comprehensive measure of investor sentiment. Since only trading volume and equity share in new issues are available and economically significant in Korea, Kim and Byun (2010) form the investor sentiment index by combining four additional variables (i.e., retail investor trading, stock fund flows, customer expectation index, customer's deposit for stock investment).

KSENT is the first principal component of the correlation matrix of six variables (BSI, FUND, CEI, CD, TURN, and SR).

Principal components analysis is performed to isolate the common sentiment components among these six variables from idiosyncratic non-sentiment-related components. Next, KBSENT is the investor sentiment index after controlling for the 
business cycle. Each of the above six proxies is regressed on the six business-cycle-related variables (i.e., the growth of industrial production, durables sales, semi-durables sales, non-durables sales, service production, and coincident composite index for business cycle changes). Then, the residuals from these regressions are used as the sentiment index controlled for business cycle.

DIFFPE is the estimate of the overall level of equity market following Conrad et al. (2002). It is based on the difference between the market price-to-earnings $(\mathrm{P} / \mathrm{E})$ ratio in the current month and the average market $\mathrm{P} / \mathrm{E}$ over the previous 12 months. Greater DIFFPE indicates that the sentiment in the current month is higher than that in the prior year.

\subsubsection{Discretionary accruals}

Accrual-based earnings management is measured by the discretionary portion of accruals. The study estimates the discretionary accruals by using the modified Jones model (Dechow et al., 1995; Kothari et al., 2005). The modified Jones model is based on the following regression equation:

$$
\begin{aligned}
& T A C_{i t}=\beta_{0}+\beta_{1} \cdot \Delta \operatorname{Rev}_{i t}+ \\
& +\beta_{2} \cdot P P E_{i t}+\beta_{3} \cdot R O A_{i, t-1}+\varepsilon_{i t},
\end{aligned}
$$

where, $T A C_{1}, T A C_{2}$ - total accruals (net income minus operating cash flows, operating income minus operating cash flows) for firm $i$ during year $t$, scaled by the total assets at the beginning of year $t, R e v$ - sales revenue for firm $i$ in year $t$, scaled by the total assets at the beginning of year $t, P P E$ - property, plant and equipment for firm $i$ at the end of year $t$, scaled by the total assets at the beginning of year $t$, and $R O A$ - return on total assets for firm $i$ in year $t-1$.

Then, the discretionary accruals $\left(D A_{1}, D A_{2}\right)$ are calculated as the difference between total accruals and non-discretionary accruals (i.e., the residuals from the regression equation 1 ).

\subsubsection{Real activity-based earnings management}

Following Roychowdhury (2006), the following cross-sectional industry-level annual regressions are used to estimate the normal level of operating cash flows, production costs, and discretionary expenses.

$$
\begin{aligned}
& \left(\frac{C F O_{t}}{A_{t-1}}\right)=\alpha_{0}+\alpha_{1} \cdot\left(\frac{1}{A_{t-1}}\right)+ \\
& +\beta_{1} \cdot\left(\frac{S_{t}}{A_{t-1}}\right)+\beta_{2} \cdot\left(\frac{\Delta S_{t}}{A_{t-1}}\right)+e_{t} \\
& \left(\frac{P R O D_{t}}{A_{t-1}}\right)=\alpha_{0}+\alpha_{1} \cdot\left(\frac{1}{A_{t-1}}\right)+ \\
& +\beta_{1} \cdot\left(\frac{S_{t}}{A_{t-1}}\right)+\beta_{2} \cdot\left(\frac{\Delta S_{t}}{A_{t-1}}\right)+\beta_{3}\left(\frac{\Delta S_{t-1}}{A_{t-1}}\right)+e_{t}, \\
& \left(\frac{D I S X_{t}}{A_{t-1}}\right)=\alpha_{0}+\alpha_{1} \cdot\left(\frac{1}{A_{t-1}}\right)+\beta_{1} \cdot\left(\frac{S_{t-1}}{A_{t-1}}\right)+e_{t},
\end{aligned}
$$

where, $C F O$ - operating cash flows during year $t, S$ - the sales revenue for year $t, A$ - the total assets at the beginning of year $t, P R O D$ - the production cost for year $t(=\mathrm{COGS}+\Delta I N V)$, and DISX - selling and general expense-TaxesDepreciation-Rent expenses-Insurance expense during year $t$.

The residuals of regression (2), (3) and (4) represent the abnormal $C F O s$, abnormal production costs, and abnormal discretionary expenses, respectively. Finally, real-based earnings management measures are defined as follows for simplicity:

$A C F O=$ abnormal $C F O \cdot(-1)$,

$A P R O D=$ abnormal $P R O D$,

$A D I S X=$ abnormal $D I S X \cdot(-1)$, and

$R E M=A C F O+A P R O D+A D I S X$.

\subsection{Empirical test model}

The following regression model is estimated to examine the research question:

$E M=\alpha+\beta_{1}$ SENT $+\beta_{2}$ Size +

$+\beta_{3}$ Leverage $+\beta_{4} R O A+\beta_{5} M T B+$

$+\beta_{6}$ Following $+\beta_{7}$ Big $4+\varepsilon$.

$E M$ is an earnings management variable: discretionary accruals $\left(D A_{1}, D A_{2}\right)$ or real-activity manipulation ( $A C F O, A P R O D, A D I S X, R E M)$. 
SENT is an investor sentiment proxy: KSENT, KBSENT or DIFFPE. The model includes several control variables that are related to earnings management: Size (natural logarithm of market capitalization), Leverage (debt-to-equity ratio), $R O A$ (net income divided by beginning total assets), MTB (market-to-book ratio), Following (a dummy variable of analyst following), and Big4 (a dummy that is set to 1 if a firm is audited by Big 4 auditors). Also, industry fixed effects are included to control for industry-specific effect on earnings management. All variables are winsorized at top $99 \%$ and bottom $1 \%$.

\subsection{Data and sample}

I collect the financial variables used in the empirical tests from the TS2000 database, which is similar to Compustat in the U.S. The sample consists of non-financial firms listed on the Korea Stock Exchange and KOSDAQ from 2003 to 2011.
The sample period ends in 2011 in which Korean International Financial Reporting Standard (K-IFRS) was adopted. Also, I delete firms with non-December fiscal year-end, impaired capital, negative total assets or negative book equity in order to ensure comparability in the sample. The final sample contains 10,723 firm-year observations (489 distinct firms).

\section{TEST RESULTS}

\subsection{Descriptive statistics}

Table 1 describes the industry composition of sample firms. Out of 489 distinct firms, about $22 \%$ belongs to manufacture of chemicals and chemical products; except pharmaceuticals and medicinal chemicals (KSIC 20) and professional services (KSIC 71). Next largest groups are evenly distributed over manufacture of food products (KSIC

Table 1. Sample firms' industry composition

\begin{tabular}{|c|c|c|}
\hline KSIC & Description & No. of firms \\
\hline 10 & Manufacture of food products & 28 \\
\hline 13 & Manufacture of textiles, except apparel & 9 \\
\hline 14 & Manufacture of wearing apparel, clothing accessories and fur articles & 12 \\
\hline 17 & Manufacture of pulp, paper and paper products & 18 \\
\hline 20 & Manufacture of chemicals and chemical products; except pharmaceuticals and medicinal chemicals & 55 \\
\hline 21 & Manufacture of pharmaceuticals, medicinal chemical and botanical products & 29 \\
\hline 22 & Manufacture of rubber and plastics products & 15 \\
\hline 23 & Manufacture of other non-metallic mineral products & 17 \\
\hline 24 & Manufacture of basic metals & 35 \\
\hline 25 & Manufacture of fabricated metal products, except machinery and furniture & 6 \\
\hline 26 & Manufacture of electronic components, computer; visual, sounding and communication equipment & 34 \\
\hline 27 & Manufacture of medical, precision and optical instruments, watches and clocks & 3 \\
\hline 28 & Manufacture of electrical equipment & 14 \\
\hline 29 & Manufacture of other machinery and equipment & 24 \\
\hline 30 & Manufacture of motor vehicles, trailers and semitrailers & 32 \\
\hline 35 & Electricity, gas, steam and air conditioning supply & 9 \\
\hline 41 & General construction & 28 \\
\hline 42 & Specialized construction activities & 2 \\
\hline 46 & Wholesale trade on own account or on a fee or contract basis & 33 \\
\hline 47 & Retail trade, except motor vehicles and motorcycles & 7 \\
\hline 49 & Land transport and transport via pipelines & 9 \\
\hline 58 & Publishing activities & 4 \\
\hline 59 & $\begin{array}{l}\text { Motion picture, video and television programme production, sound recording and music publishing } \\
\text { activities }\end{array}$ & 3 \\
\hline 62 & Computer programming, consultancy and related activities & 6 \\
\hline 63 & Information service activities & 1 \\
\hline 71 & Professional services & 52 \\
\hline 75 & Business support services & 4 \\
\hline Sum & & 489 \\
\hline
\end{tabular}


Table 2. Descriptive statistics

\begin{tabular}{|c|c|c|c|c|c|c|c|c|}
\hline Variable & $\mathbf{N}$ & Mean & STDEV & MIN & P25 & Median & P75 & MAX \\
\hline $\mathrm{DA} 1$ & 10.723 & 0.0092 & 0.0666 & -0.1771 & -0.0294 & 0.0065 & 0.0440 & 0.2181 \\
\hline DA2 & 10.723 & 0.0043 & 0.0767 & -0.2364 & -0.0368 & 0.0046 & 0.0455 & 0.2343 \\
\hline REM & 10.723 & 0.0032 & 0.1942 & -0.7376 & -0.0952 & 0.0188 & 0.1143 & 0.4742 \\
\hline ACFO & 10.723 & -0.0004 & 0.0690 & -0.1957 & -0.0419 & 0.0000 & 0.0408 & 0.1918 \\
\hline ADISC & 10.723 & 0.0009 & 0.0793 & -0.3321 & -0.0274 & 0.0105 & 0.0426 & 0.1747 \\
\hline APROD & 10.723 & 0.0027 & 0.0988 & -0.3568 & -0.0456 & 0.0073 & 0.0573 & 0.2840 \\
\hline KSENT & 10.723 & -0.0922 & 0.6211 & -1.3074 & -0.3052 & -0.0001 & 0.2487 & 1.7127 \\
\hline KBSENT & 10.723 & -0.0608 & 0.6318 & -0.9205 & -0.6975 & -0.0343 & 0.1824 & 1.1539 \\
\hline DIFFPE & 10.723 & 0.0803 & 0.7367 & -1.2371 & -0.3519 & -0.0496 & 0.8520 & 1.0766 \\
\hline SIZE & 10.723 & 12.8250 & 1.4248 & 10.2422 & 11.7754 & 12.5774 & 13.7093 & 17.0018 \\
\hline LEV & 10.723 & 0.4402 & 0.1902 & 0.0563 & 0.3023 & 0.4468 & 0.5793 & 0.8933 \\
\hline MTB & 10.723 & 0.2154 & 0.4530 & 0.0012 & 0.0196 & 0.0671 & 0.2027 & 3.0702 \\
\hline $\mathrm{ROA}$ & 10.723 & 0.0387 & 0.0764 & -0.2660 & 0.0112 & 0.0409 & 0.0786 & 0.2220 \\
\hline Following & 10.723 & 0.4302 & 0.4951 & 0 & 0 & 0 & 1 & 1 \\
\hline Big 4 & 10.723 & 0.6429 & 0.4792 & 0 & 0 & 1 & 1 & 1 \\
\hline
\end{tabular}

10), manufacture of pharmaceuticals, medicinal chemical and botanical products (KSIC 21), manufacture of basic metals (KSIC 24), manufacture of electronic components, computer; visual, sounding and communication equipment (KSIC 26), manufacture of motor vehicles, trailers and semitrailers (KSIC 30), general construction (KSIC 41), wholesale trade on own account or on a fee or contract basis (KSIC 46).

Table 2 provides the summary statistics of test variables. The means of discretionary accruals and real-based earnings management measures $\left(D A_{1}, D A_{2}, R E M\right)$ are $0.0092,0.0043$, and 0.0032 , respectively. Sample firms have average size of 12.8250 , debt ratio of 0.4402 , market-tobook ratio of 0.2154 , and $R O A$ of 0.0387 . Also, $43 \%$ and $64 \%$ of sample firms are followed by analysts and audited by Big 4 firms.

\subsection{Main test results}

\subsubsection{Effect of investor sentiment on discretionary accruals}

Table 3 exhibits the test results on the relationship between investor sentiment and accrualbased earnings management. Panel $\mathrm{A}$ and $\mathrm{B}$ are based on the OLS regression analyses using $D A_{1}$ and $D A_{2}$ as the dependent variable, respective- ly. In both tables, all investor sentiment proxies (KSENT, KBSENT, DIFFPE) are negatively associated with discretionary accruals. Also, these negative correlations are statistically significant at the $1 \%$ level. This indicates that firms tend to manipulate earnings upward using positive discretionary accruals when the investor sentiment is pessimistic.

\subsubsection{Effect of investor sentiment on real-based earnings management}

Table 4 exhibits the test results on the relationship between investor sentiment and real activity-based earnings management. Panel A, B, C and $\mathrm{D}$ are based on the OLS regression analyses using $A C F O, A D I S X, A P R O D$ and $R E M$ as the dependent variable, respectively. In all panels, all investor sentiment proxies (KSENT, KBSENT, DIFFPE) are not significantly related to the measures of real-based earnings management.

Collectively, these findings suggest that firms do not appear to rely on changing their real operating activities such as timing of sales, $R \& D$ and production to report favorable earnings. Rather, firms tend to use discretionary accruals to boost reported income in bad times. Hence, the means of earnings management appear to vary with investor sentiment. 
Table 3. Investor sentiment and discretionary accruals

\begin{tabular}{|c|c|c|c|c|c|c|c|c|c|c|}
\hline Variable & $\begin{array}{c}\text { Predicted } \\
\text { sign }\end{array}$ & Parameter & t-value & & Parameter & t-value & & Parameter & t-value & \\
\hline \multicolumn{11}{|c|}{ Panel A: Dependent variable = DA1 } \\
\hline Intercept & - & 0.032 & 4.74 & $* * *$ & 0.033 & 4.95 & $* * *$ & 0.037 & 5.10 & $* * *$ \\
\hline KSENT & - & -0.008 & -8.48 & $* * *$ & - & - & - & - & - & - \\
\hline KBSENT & - & - & - & $-\ldots$ & -0.005 & -4.98 & $* * *$ & - & - & - \\
\hline DIFFPE & - & - & - & - & - & - & - & -0.007 & -8.51 & $* * *$ \\
\hline Size & - & -0.004 & -7.16 & $* * *$ & -0.004 & -7.32 & $* * *$ & -0.004 & -7.11 & $* * *$ \\
\hline Leverage & + & 0.064 & 17.88 & $* * *$ & 0.064 & 17.70 & $* * *$ & 0.066 & 17.23 & $* * *$ \\
\hline MTB & + & -0.001 & -0.42 & - & -0.001 & -0.67 & - & -0.001 & -0.42 & - \\
\hline ROA & - & 0.119 & 13.74 & $* * *$ & 0.114 & 13.16 & $* * *$ & 0.115 & 12.51 & $* * *$ \\
\hline Following & + & 0.003 & 1.77 & $*$ & 0.003 & 2.13 & $*$ & 0.003 & 1.92 & $*$ \\
\hline Big4 & - & -0.003 & -2.41 & $* *$ & -0.003 & -1.95 & $*$ & -0.003 & -2.17 & $* *$ \\
\hline \multicolumn{2}{|c|}{ Industry fixed effect } & \multicolumn{3}{|c|}{ Included } & \multicolumn{3}{|c|}{ Included } & \multicolumn{3}{|c|}{ Included } \\
\hline \multicolumn{2}{|l|}{ F value } & \multicolumn{3}{|c|}{23.58} & \multicolumn{3}{|c|}{22.02} & \multicolumn{3}{|c|}{23.45} \\
\hline \multicolumn{2}{|l|}{ Adj R-sq } & \multicolumn{3}{|c|}{0.0579} & \multicolumn{3}{|c|}{0.0541} & \multicolumn{3}{|c|}{0.06} \\
\hline \multicolumn{11}{|c|}{ Panel B: Dependent variable $=$ DA2 } \\
\hline Intercept & - & 0.057 & 7.78 & $* * *$ & 0.058 & 7.92 & *** & 0.060 & 7.77 & $* * *$ \\
\hline KSENT & - & -0.008 & -7.16 & $* * *$ & - & - & - & - & - & - \\
\hline KBSENT & - & - & - & - & -0.003 & -3.38 & $* * *$ & - & - & - \\
\hline DIFFPE & - & - & - & - & - & - & - & -0.004 & -4.04 & $* * *$ \\
\hline Size & - & -0.006 & -9.99 & $* * *$ & -0.006 & -10.08 & $* * *$ & -0.006 & -9.53 & $* * *$ \\
\hline Leverage & + & 0.036 & 9.35 & $* * *$ & 0.036 & 9.16 & $* * *$ & 0.035 & 8.6 & $* * *$ \\
\hline MTB & + & -0.002 & -1.67 & $*$ & -0.003 & -1.89 & $*$ & -0.002 & -1.52 & \\
\hline ROA & - & 0.454 & 48.26 & $* * *$ & 0.449 & 47.77 & $* * *$ & 0.452 & 45.35 & $* * *$ \\
\hline Following & + & -0.012 & -7.4 & $* * *$ & -0.012 & -7.08 & $* * *$ & -0.012 & -7.07 & $* * *$ \\
\hline Big4 & - & -0.002 & -1.22 & & -0.001 & -0.79 & - & -0.002 & -1.12 & - \\
\hline \multicolumn{2}{|c|}{ Industry fixed effect } & \multicolumn{3}{|c|}{ Included } & \multicolumn{3}{|c|}{ Included } & \multicolumn{3}{|c|}{ Included } \\
\hline \multicolumn{2}{|l|}{ F value } & \multicolumn{3}{|c|}{80.95} & \multicolumn{3}{|c|}{79.44} & \multicolumn{3}{|c|}{72.23} \\
\hline \multicolumn{2}{|l|}{ Adj R-sq } & \multicolumn{3}{|c|}{0.1787} & \multicolumn{3}{|c|}{0.1759} & \multicolumn{3}{|c|}{0.1753} \\
\hline
\end{tabular}

Note: All t-values are based on two-tailed t-tests. ${ }^{* *},{ }^{* *}$, and ${ }^{*}$ indicate the statistical significance at $1 \%, 5 \%$, and $10 \%$ levels, respectively.

Table 4. Investor sentiment and real-based earnings management

\begin{tabular}{|c|c|c|c|c|c|c|c|c|c|c|}
\hline Variable & $\begin{array}{c}\text { Predicted } \\
\text { sign }\end{array}$ & Parameter & t-value & & Parameter & t-value & & Parameter & t-value & \\
\hline \multicolumn{11}{|c|}{ Panel A: Dependent variable = ACFO } \\
\hline Intercept & - & 0.067 & 10.08 & $* * *$ & 0.048 & 7.23 & $* * *$ & 0.066 & 9.09 & $* * *$ \\
\hline KSENT & - & 0.000 & 0.43 & - & - & - & - & - & - & - \\
\hline KBSENT & - & - & - & - & 0.001 & 1.11 & - & - & - & - \\
\hline DIFFPE & - & - & - & - & - & - & - & 0.000 & -0.32 & - \\
\hline Size & - & -0.005 & -9.41 & $* * *$ & -0.003 & -6.09 & $* * *$ & -0.006 & -9.78 & $* * *$ \\
\hline Leverage & + & 0.047 & 13.36 & $* * *$ & 0.099 & 20.83 & $* * *$ & 0.067 & 18.55 & $* * *$ \\
\hline MTB & + & -0.004 & -3.24 & $* * *$ & -0.003 & -1.93 & $* *$ & -0.001 & -1.62 & $*$ \\
\hline ROA & - & -0.268 & -31.24 & $* * *$ & -0.256 & -30.69 & $* * *$ & -0.100 & -18.99 & $* * *$ \\
\hline Following & + & -0.004 & -2.97 & $* * *$ & -0.003 & -1.82 & $*$ & -0.011 & -6.95 & $* * *$ \\
\hline Big4 & - & -0.001 & -0.47 & - & 0.000 & 0.26 & - & -0.003 & -2.18 & $* *$ \\
\hline \multicolumn{2}{|c|}{ Industry fixed effect } & \multicolumn{3}{|c|}{ Included } & \multicolumn{3}{|c|}{ Included } & \multicolumn{3}{|c|}{ Included } \\
\hline \multicolumn{2}{|l|}{ F value } & \multicolumn{3}{|c|}{67.56} & \multicolumn{3}{|c|}{76.84} & \multicolumn{3}{|c|}{44.94} \\
\hline Adj R-sq & & \multicolumn{3}{|c|}{0.1534} & \multicolumn{3}{|c|}{0.1711} & \multicolumn{3}{|c|}{0.1159} \\
\hline
\end{tabular}


Table 4 (cont). Investor sentiment and real-based earnings management

\begin{tabular}{|c|c|c|c|c|c|c|c|c|c|c|}
\hline Variable & $\begin{array}{c}\text { Predicted } \\
\text { sign }\end{array}$ & Parameter & t-value & & Parameter & t-value & & Parameter & t-value & \\
\hline \multicolumn{11}{|c|}{ Panel B: Dependent variable $=$ ADISX } \\
\hline Intercept & - & 0.010 & 1.29 & - & 0.009 & 1.13 & & 0.001 & 0.12 & - \\
\hline KSENT & - & 0.000 & -0.35 & - & - & - & - & - & - & - \\
\hline KBSENT & - & - & - & - & -0.001 & -0.59 & - & - & - & - \\
\hline DIFFPE & - & - & - & - & - & - & - & 0.002 & 1.37 & - \\
\hline Size & - & 0.001 & 2.28 & $* *$ & 0.001 & 1.38 & & 0.002 & 2.61 & $* *$ \\
\hline Leverage & + & -0.020 & -4.68 & $* * *$ & 0.004 & 0.68 & & -0.019 & -4.01 & $* * *$ \\
\hline MTB & + & -0.011 & -6.52 & $* * *$ & -0.012 & -7.63 & $* * *$ & -0.001 & -2.37 & $* *$ \\
\hline ROA & - & -0.042 & -4 & $* * *$ & -0.024 & -2.37 & $* *$ & 0.011 & 1.58 & - \\
\hline Following & + & -0.011 & -5.91 & $* * *$ & -0.010 & -5.58 & $* * *$ & -0.017 & -7.88 & $* * *$ \\
\hline Big4 & - & -0.006 & -3.88 & $* * *$ & -0.006 & -3.63 & $* * *$ & -0.008 & -3.98 & $* * *$ \\
\hline \multicolumn{2}{|c|}{ Industry fixed effect } & \multicolumn{3}{|c|}{ Included } & \multicolumn{3}{|c|}{ Included } & \multicolumn{3}{|c|}{ Included } \\
\hline \multicolumn{2}{|l|}{ F value } & \multicolumn{3}{|c|}{12.38} & \multicolumn{3}{|c|}{11.69} & \multicolumn{3}{|c|}{12.29} \\
\hline \multicolumn{2}{|l|}{ Adj R-sq } & \multicolumn{3}{|c|}{0.03} & \multicolumn{3}{|c|}{0.0283} & \multicolumn{3}{|c|}{0.0326} \\
\hline \multicolumn{11}{|c|}{ Panel C: Dependent variable $=$ APROD } \\
\hline Intercept & - & 0.028 & 2.84 & $* *$ & 0.021 & 2.14 & $* *$ & 0.002 & 0.2 & - \\
\hline KSENT & - & 0.002 & 1.46 & - & - & - & - & - & - & - \\
\hline KBSENT & - & - & - & - & 0.002 & 1.59 & - & - & - & - \\
\hline DIFFPE & - & - & - & - & - & - & - & 0.002 & 1.48 & - \\
\hline Size & - & 0.000 & 0.26 & - & 0.001 & 1.16 & & 0.001 & 0.94 & - \\
\hline Leverage & + & 0.017 & 3.23 & $* * *$ & 0.032 & 4.56 & $* * *$ & 0.034 & 5.57 & $* * *$ \\
\hline MTB & + & -0.013 & -6.34 & $* * *$ & -0.012 & -6.07 & $* * *$ & -0.001 & -1.42 & \\
\hline ROA & - & -0.313 & -24.8 & $* * *$ & -0.310 & -24.97 & $* * *$ & -0.113 & -12.91 & $* * *$ \\
\hline Following & + & -0.009 & -4.26 & $* * *$ & -0.009 & -4.07 & $* * *$ & -0.023 & -8.62 & $* * *$ \\
\hline Big 4 & - & -0.004 & -2.02 & $* *$ & -0.004 & -1.92 & $* *$ & -0.007 & -2.92 & $* *$ \\
\hline \multicolumn{2}{|c|}{ Industry fixed effect } & \multicolumn{3}{|c|}{ Included } & \multicolumn{3}{|c|}{ Included } & \multicolumn{3}{|c|}{ Included } \\
\hline \multicolumn{2}{|l|}{ F value } & \multicolumn{3}{|c|}{34.1} & \multicolumn{3}{|c|}{34.44} & \multicolumn{3}{|c|}{16.67} \\
\hline Adj R-sq & & & 0.0827 & & & .0834 & & & 0.0447 & \\
\hline & & & $\overline{\text { Panel D }}$ & Dep & ndent variab & $l e=$ REM & & & & \\
\hline Intercept & - & 0.107 & 5.61 & $* * *$ & 0.080 & 4.16 & $* * *$ & 0.070 & 3.07 & $* * *$ \\
\hline KSENT & - & 0.002 & 0.61 & - & - & - & - & - & - & - \\
\hline KBSENT & - & - & - & - & 0.002 & 0.82 & - & - & - & - \\
\hline DIFFPE & - & - & - & - & - & - & - & 0.003 & 1.26 & - \\
\hline Size & - & -0.004 & -2.31 & $* *$ & -0.002 & -1.06 & - & -0.003 & -1.56 & - \\
\hline Leverage & + & 0.044 & 4.3 & $* * *$ & 0.137 & 9.96 & $* * *$ & 0.082 & 7.27 & $* * *$ \\
\hline МTB & + & -0.028 & -7.22 & $* * *$ & -0.027 & -7.13 & $* * *$ & -0.003 & -2.26 & $* *$ \\
\hline ROA & - & -0.626 & -25.38 & $* * *$ & -0.592 & -24.52 & $* * *$ & -0.202 & -12.34 & $* * *$ \\
\hline Following & + & -0.024 & -5.68 & $* * *$ & -0.022 & -5.04 & $* * *$ & -0.051 & -10.09 & $* * *$ \\
\hline Big 4 & - & -0.011 & -2.86 & $* *$ & -0.009 & -2.45 & $* *$ & -0.018 & -3.9 & $* * *$ \\
\hline Industry fixed & ffect & & cluded & & & cluded & & & ncluded & \\
\hline F value & & & 40.78 & & & 43.56 & & & 21.98 & \\
\hline Adj R-sq & & & 0.0977 & & & .1038 & & & 0.0589 & \\
\hline
\end{tabular}

Note: All t-values are based on two-tailed t-tests. ${ }^{* *},{ }^{* *}$, and ${ }^{*}$ indicate the statistical significance at $1 \%, 5 \%$, and $10 \%$ levels, respectively.

\section{CONCLUSION}

Using a sample of public companies on Korea Securities Market from 2003 to 2011, this paper show that firms do not rely on real activity manipulation rather they tend to inflate earnings using discretionary accruals in bad economic times. Consistent with Graham et al. (2005), managers tend to use positive discretionary accruals in recessions because intrinsic earnings will increase when the economy recovers which leads to the reversal or catch-up. 
These results add new evidence to accounting literature that managers do not manipulate operating activities to boost reported income in bad times, but they tend to rely on accrual-based manipulation. Also,the paper has marginal contribution by showing that accrual quality is affected by investor sentiment, but real-based managementis relatively free from such bias.

\section{REFERENCES}

1. Baker, M., \& Wurgler, J. (2006). Investor sentiment and the cross-section of stock returns. The Journal of Finance, 61(4), 16451680. https://doi.org/10.1111/ j.1540-6261.2006.00885.x

2. Baker, M., \& Wurgler, J. (2007). Investor sentiment in the stock market. The Journal of Economic Perspectives, 21(2), 129-151. https://doi.org/10.3386/w13189

3. Cohen, D. A., \& Zarowin, P. (2010). Accrual-based and real earnings management activities around seasoned equity offerings. Journal of Accounting and Economics, 50(1), 2-19. https://doi. org/10.1016/j.jacceco.2010.01.002

4. Conrad, J., Cornell, B., \& Landsman, W. R. (2002). When is bad news really bad news? The Journal of Finance, 57(6), 2507-2532. https://doi. org/10.1111/1540-6261.00504

5. Dechow, P. M., Sloan, R. G., \& Sweeney, A. P. (1995). Detecting earnings management. Accounting Review, 193-225. Retrieved from http://www.jstor.org/stable/248303
6. Graham, J. R., Harvey, C. R., \& Rajgopal, S. (2005). The economic implications of corporate financial reporting. Journal of Accounting and Economics, 40(1), 3-73. https://doi.org/10.3386/ w10550

7. Kim, K., \& Byun, J. (2010). Effect of Investor Sentiment on Market Response to Stock Split Announcement. Asia-Pacific Journal of Financial Studies, 39(6), 687-719. https://doi.org/10.1111/ j.2041-6156.2010.01029.x

8. Kothari, S. P., Leone, A. J., \& Wasley, C. E. (2005). Performance matched discretionary accrual measures. Journal of Accounting and Economics, 39(1), 163-197. https://doi.org/10.1016/j.jacceco.2004.11.002

9. Park, S. (2015). Investor sentiment and earnings management: evidence from Korea. Investment Management and Financial Innovations, 12(4), 80-88. Retrieved from https:// businessperspectives.org/journals/investment-management- and-financial-innovations/ issue-101/investor-sentimentand-earnings-management-evidence-from-korea

10. Roychowdhury, S. (2006). Earnings management through real activities manipulation. Journal of Accounting and Economics, 42(3), 335-370. https://doi.org/10.1016/j.jacceco.2006.01.002

11. Schipper, K. (1989). Commentary on earnings management. Accounting Horizons, 3(4), 91-102. https://doi.org/10.12691/jfa-3-3-3

12. Song, I., Paek W., \& Park, H. S. (2004) Earnings management for the avoidance of losses. Korean Accounting Journal, 13(2), 29-51. https://doi.org/10.1016/S01654101(97)00017-7

13. Zang, A. Y. (2011). Evidence on the trade-off between real activities manipulation and accrual-based earnings management. The Accounting Review, 87(2), 675-703. https://doi. org/10.2308/accr-10196 